\title{
Pulmonary and hepatic granulomatous disorders due to the inhalation of cement and mica dusts
}

\author{
J. CORTEZ PIMENTEL AND A. PEIXOTO MENEZES ${ }^{1}$
}

From the Department of Pathology of Sanatorio D. Carlos I and Institute of Pathology, University of Lisbon, Faculty of Medicine, Lisbon, Portugal

Cortez Pimentel, J., and Peixoto Menezes, A. (1978). Thorax, 33, 219-227. Pulmonary and hepatic granulomatous disorders due to the inhalation of cement and mica dusts. Hepatic and pulmonary granulomas were recognised in two workers exposed respectively to Portland cement and to muscovite dusts. The pulmonary lesions in the patient exposed to cement consisted of histiocytic granulomas and irregular fibrohyaline scars, and in the patient exposed to mica of a diffuse thickening of all interalveolar septa due to new formation of reticulin and collagen fibres and proliferation of fibroblasts and histiocytes. In the liver the following pathological findings were observed: focal or diffuse swelling of sinusoidal lining cells, sarcoid-type granulomas, and, in the case of mica exposure, perisinusoidal and portal tract fibrosis. Abundant inclusions of the inhaled material were identified within the pulmonary and hepatic lesions by histochemical and $x$-ray diffraction techniques.

The inhalation of dusts containing silicon is known to produce different kinds of pneumoconiosis. Although free silica is sometimes the only pathogenic dust inhaled, in most situations there is exposure to silicates (for example, mica, asbestos, kaolin, talc) or to mixed dusts of free or combined silica and other inorganic dusts such as cement. The pathological findings produced by the latter type of dusts do not mimic the typical pattern of silicosis, and their diagnosis is based on the occupational history of the patient and on the identification of the inhaled foreign material within the lesions.

The effects of cement and mica dusts on the human respiratory tract have been recognised in epidemiological surveys (Middleton, 1936; Sayers et al., 1937; Gardner et al., 1939; Dreesen et al., 1940; Vestal et al., 1943; Giuliani and Belli, 1955; Jenny et al., 1960 Hublet, 1968; Kalačić, 1973). Nevertheless, there are few references to the pulmonary histopathology (Doerr, 1952; Vorwald, 1960; Pimentel and Gomes, 1973), and other possible causes of pneumoconiosis were not excluded in some reports (Doerr, 1952; Vorwald, 1960). There is also some controversy over the experi-

'Present address: Laboratory of Pathophysiology, National Cancer Institute, National Institutes of Health, Bethesda, Maryland 20014, U.S.A. mental pathogenic effects of cement and mica (Lemon and Higgins, 1935; Baetjer, 1947; King et al., 1947, 1950; Einbrodt and Hentschel, 1966; Tripsa and Rotaru, 1966; Pimentel and Gomes, 1973).

In addition to causing pulmonary lesions, exposure to pathogenic dusts may produce hepatic granulomas, as described in silicosis (Cisno et al., 1971), berylliosis (Chesner, 1950), and vineyard sprayer's lung (Pimentel and Menezes, 1975).

\section{Case reports}

CASE 1

A 57-year-old man who had been exposed to cement dust for 28 years in a Portland cement plant complained of cough and mucopurulent sputum, weakness, and loss of weight since July 1967. One month later haemoptysis occurred. A chest radiograph showed reticular and micronodular shadows in the lower third of both lungs and areas of transparency in the right upper lobe. No acid-fast bacilli were found in the sputum. Liver function tests were normal. The patient was treated with isoniazid and ethambutol without improvement. Pulmonary function tests revealed a moderate degree of restrictive ventilatory defect with some obstruction. Diffusing capacity was normal. In August 1968 he had a right upper lobec- 
tomy but died after surgery with a myocardial infarction. Histological examination of the lungs revealed that the areas of transparency seen on the radiograph corresponded to bronchiectasis surrounded by pigmented scars. Widespread greyblack, irregular or nodular scars, $3 \mathrm{~mm}$ in diameter, were observed in both lungs, accompanied in some areas by extensive fibrous bands. The liver showed numerous grey nodules, smaller than those in the lungs.

\section{CASE 2}

A 46-year-old woman had been exposed to the inhalation of mica dust during grinding and packaging operations for seven years. In March 1971 she was admitted to hospital for dyspnoea on exertion, progressive weakness, and loss of weight. Symptoms had appeared two years before admission after a 'common cold'. There was no previous history of respiratory diseases. During this period antituberculosis drugs (streptomycin and isoniazid) were used without benefit; the sputum was persistently negative for tubercle bacilli. Physical examination revealed fine crackles in both lungs and an enlarged liver, three finger-breadths below the right costal margin, with a smooth hard edge. A chest radiograph showed bilateral reticulomicronodular shadows and some nodular densities in the left lower lobe. Serum protein electrophoresis showed: total protein $82 \mathrm{~g} / \mathrm{l}$; albumin $32.6 \%$; globulins $\alpha_{1} 6.5 \%, \alpha_{2} 13.4 \%, \beta 19.4 \%, \gamma 28 \cdot 1 \%$. Liver function tests revealed: total cholesterol $155 \mathrm{mg}$ per $100 \mathrm{ml}(4.0 \mathrm{mmol} / \mathrm{l})(60 \%$ esterified $)$,

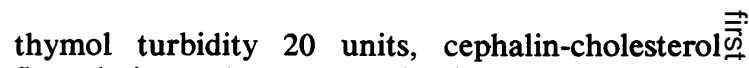
flocculation 3+; serum alkaline phosphatase $6 \circ$ Bodansky units; SGOT 270 units per ml; SGPT흘 170 units per ml; prothrombin time $80 \%$. Pul- $\frac{\bar{s}}{-}$ monary function tests revealed a restrictive venti- $\stackrel{\mathbb{D}}{\circ}$ latory pattern with hypoxaemia and hypocapnia® and marked reduction of diffusing capacity. The

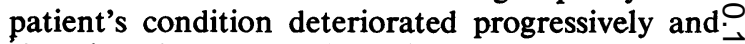
she died three years later in respiratory failure. $\vec{\omega}$ The lungs at necropsy were dark grey and were $\circ$ of a hard, rubbery consistency. Extensive areas of $\vec{x}$ diffuse fibrosis, emphysematous foci, and honey- $\dot{\omega}_{\text {. }}$ combing were observed. No macroscopic changes were observed in the liver.

\section{Histological studies}

Microscopy of the lung of case 1 revealed that the lesions around the bronchiectasis consisted of granulomas made up of histiocytic and fibro- $\vec{\theta}$ blastic cells. These granulomas were frequently observed in the peribronchovascular connective tissue and in the interalveolar septa (Fig. 1). Tran-o sitions between granulomas and irregular fibro-s hyaline scars destroying alveolar structures were also observed. Both granulomas and scars con- $\frac{\mathrm{Q}}{\varnothing}$

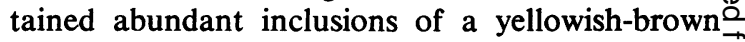
granular material with birefringent particles (Fig. $\overrightarrow{\vec{B}}$ 2). The liver showed sarcoid-type granulomas (Fig. 3) and swelling and diffuse proliferation of sinusoidal lining cells. The cells of these hepatic lesions as well as some histiocytic cells in the portal tracts contained inclusions of a materialo

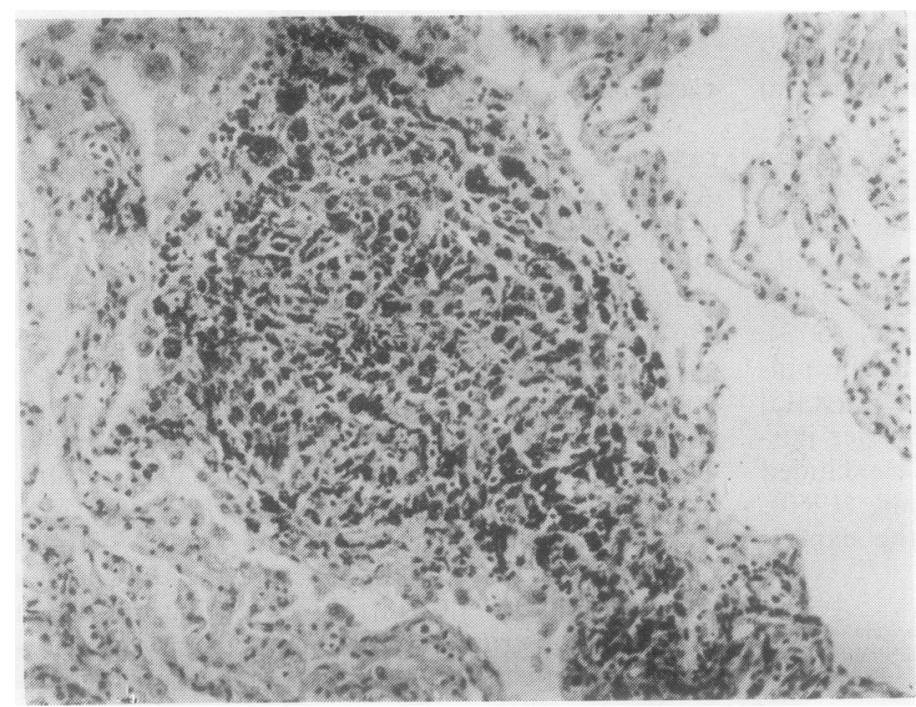

Fig. 1 Case 1. Lung. Histiocytic granuloma in an interalveolar septum, containing abundant inclusions of yellowish-brown material (Haematoxylin and eosin $\times 70)$. 


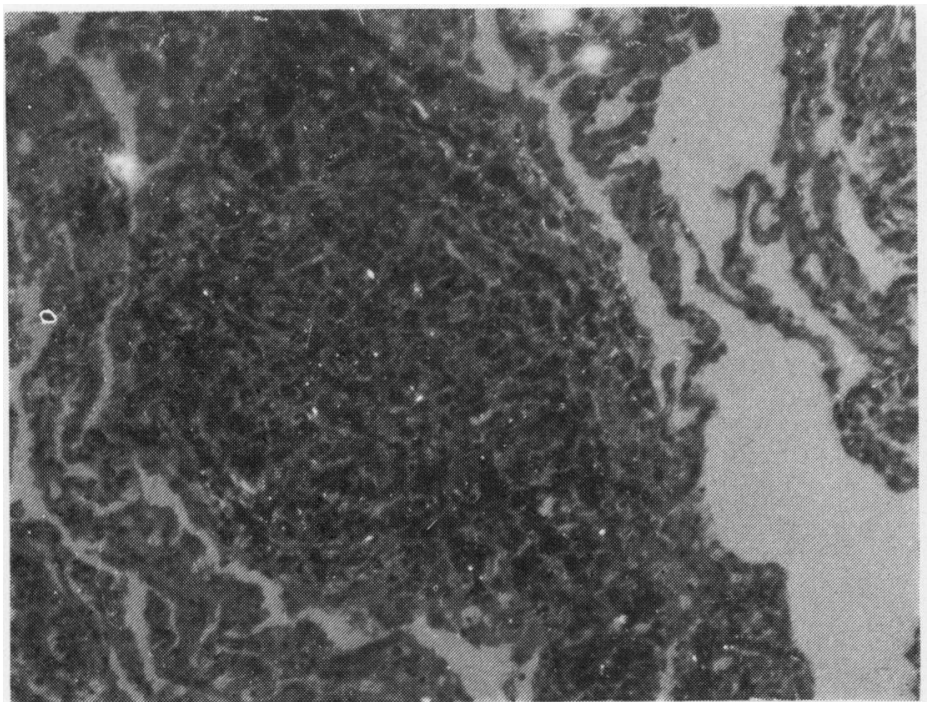

Fig. 2 The same granuloma as in Fig. 1 observed under polarised light. Birefringent particles (alite, belite, and tobermorite crystals) are observed among the foreign material inclusions $(\times 70)$.

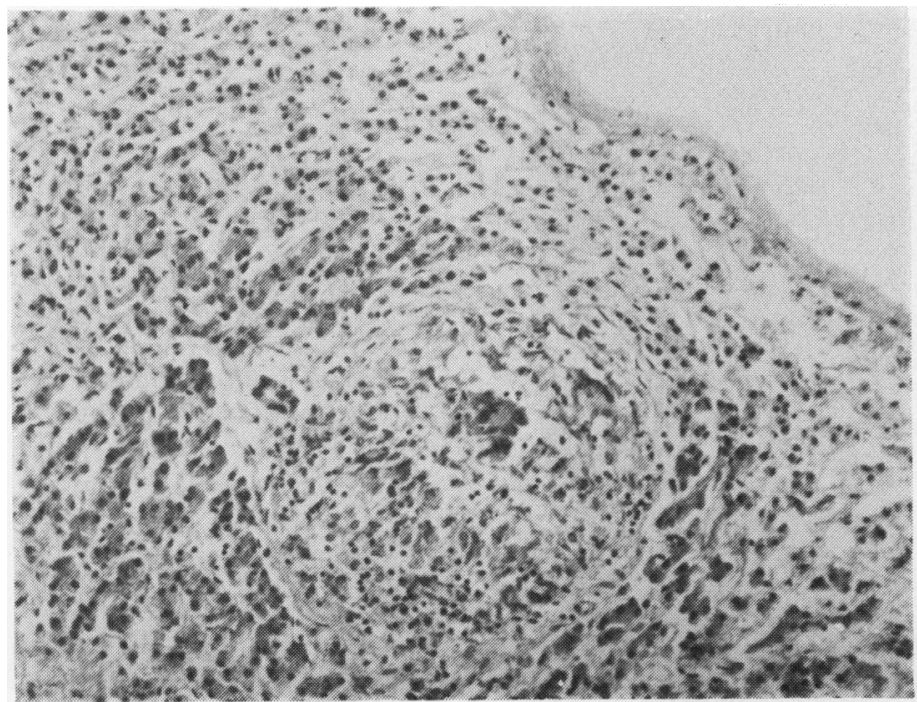

Fig. 3 Case 1. Liver. Sarcoid granuloma $(H$ and $E \times 95)$.

with the same characteristics as that observed in the lung (Fig. 4). Capsular, perisinusoidal, or portal tract fibrosis was not observed.

The lung of case 2 presented a diffuse thickening of the interalveolar septa by proliferation of histiocytes and fibroblasts and formation of reticulin and collagen fibres. A dark brown or black material and birefringent crystals were identified within these lesions (Fig. 5). In the liver the following pathological findings were observed: focal or diffuse swelling of sinusoidal lining cells, clusters of epithelioid cells organised in sarcoid- type granulomas, and fibrosis of variable intensity of portal and perisinusoidal areas. There was no capsular fibrosis. Crystals and dark brown inclusions were also identified within the hepatic lesions.

\section{Identification of cement and mica}

\section{METHODS}

The chemical composition of Portland cement to which case 1 had been exposed is: calcium oxide $62-66 \%$, silicon dioxide $19-22 \%$, aluminium trioxide $4-8 \%$, ferric oxide $2-5 \%$, magnesium oxide 

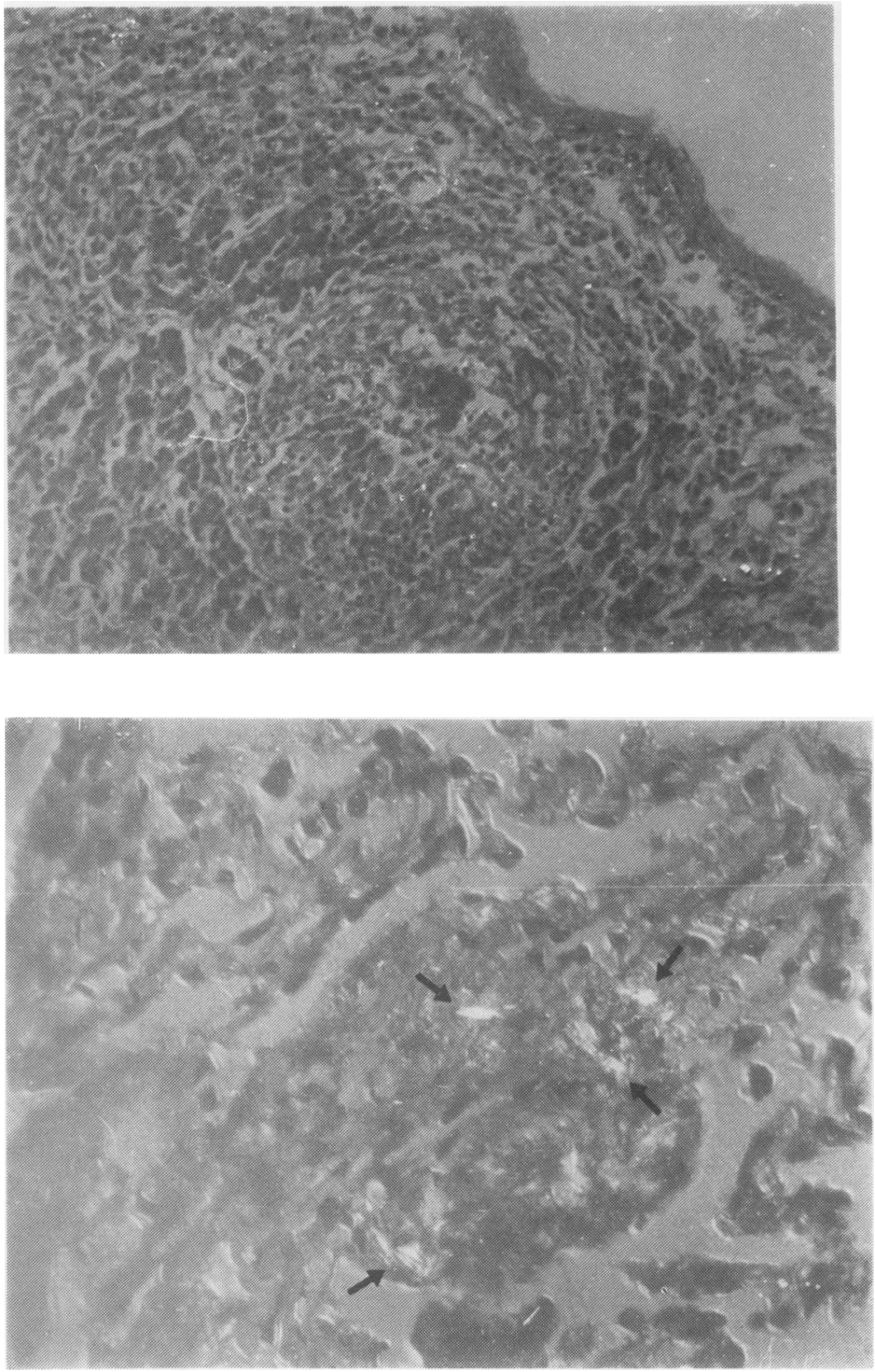

Fig. 4 The same sarcoid granuloma as in Fig. 3 observed under polarised light. Birefringent inclusions similar to those of the lung are evident within the lesions $(\times 95)$.

Fig. 5 Case 2. Lung. Diffuse thickening of the septa. Plate-like crystals of muscovite (arrows) are observed with a differential interference contrast microscope ( $H$ and $E \times 95$ ).
$1-2 \%$, and an insoluble residue $0 \cdot 6-1 \cdot 2 \%$ containing around $0.1 \%$ free silica. The components of Portland cement are arranged in an interstitial phase with aluminates and iron-aluminates of calcium and a crystalline phase with alite and belite crystals of calcium silicate, and in hydrated cement tobermorite crystals.

Mica is a mineral silicate constituent of granite and other rocks. Muscovite, a type of mica widely used in industry, consists of thin plate-like crystals of silicate of aluminium with potassium.

Considering the physical and chemical composi- tion of the dusts inhaled by the patients, samples of cement (in powder and hydrated) and mica were observed under polarised light, and histochemical techniques for the identification of calcium $\stackrel{\infty}{\oplus}$ (Kossa), iron (Perls), and aluminium (aluminon) were used (Pearse, 1972). The same methods were applied to fresh and paraffin sections of $10 \% \mathbb{D}$ neutral formaldehyde-fixed specimens of the lung and liver of the patients.

The Debye and Scherrer $x$-ray diffraction powder technique was applied to samples of 8 cement and mica and to formalin-fixed ashed 
specimens of the lung and liver of the patients; normal tissues were used as control. $X$-ray diffraction patterns were recorded in a Philips' DebyeScherrer type powder camera $(114.59 \mathrm{~mm}$ diameter). Nickel-filtered copper $\mathbf{K}_{\alpha}$ radiation produced at $40 \mathrm{kV}$ and $20 \mathrm{~mA}$ was used. Exposure time varied from 2.30 to 3 hours. The $x$-ray diffraction patterns were converted into interplanar spacings (d values) with appropriate tables (National Bureau of Standards, 1950), and the relative intensities of their lines were estimated by visual comparison.

\section{Results}

When histochemical techniques for calcium, iron, and aluminium are applied to Portland cement, a strongly positive reaction is obtained. Under polarised light, alite, belite, and tobermorite crystals can be identified: alite and belite crystals contain calcium, but whereas alite crystals are polygonal, belite crystals have an irregular shape; tobermorite crystals present a characteristic platelike structure. Inclusions observed in the pulmonary and hepatic lesions of case 1 presented the characteristics of Portland cement.

Mica appeared as crystals with polygonal profile and laminated structure under polarised light. A positive reaction was obtained with the aluminon method. The material observed in case 2 presented a similar appearance (Fig. 6).

Figures 7 and 8 show the $x$-ray powder diffraction patterns obtained from cases 1 and 2 . The interplanar d-spacing values, expressed in Äng- strom, and the relative intensities of the lines are listed in Tables 1 and 2. Comparison of the standard pattern with those of the lung and liver of the patients established that Portland cement and muscovite were present within the lesions. The diffraction lines from the lung are more intense because of the greater amount of the crystalline material. Normal tissues, used as controls, did not present diffraction lines, and lines of ferritin, haemosiderin or other biological substances were not identified in control or pathological tissues.

\section{Discussion}

The pathogenic effects produced by the inhalation of cement and mica dusts have been the subject of controversy (Jones, 1933; Parkes, 1974). The prevalence of respiratory disease of cement industry workers in different countries varied, and some authors have attempted to correlate the noxious effects of cement with its free silica content (Sayers et al., 1937; Gardner et al., 1939; Giuliani and Belli, 1955; Jenny et al., 1960; Einbrodt and Hentschel, 1966; Hublet, 1968; Parkes, 1974). Doerr (1952) reported pulmonary pathological findings at necropsy in a man exposed to cement dust, although he was also exposed to quartz dusts, and a pseudotumoral silicosis cannot be excluded considering the silicotic-type concentric arrangement of collagen bundles in the lesions (Doerr, 1952; Pimentel and Gomes, 1973; Parkes, 1974). As to mica, although radiographic and functional respiratory abnormalities have been observed in the survey of workers exposed (Middle-

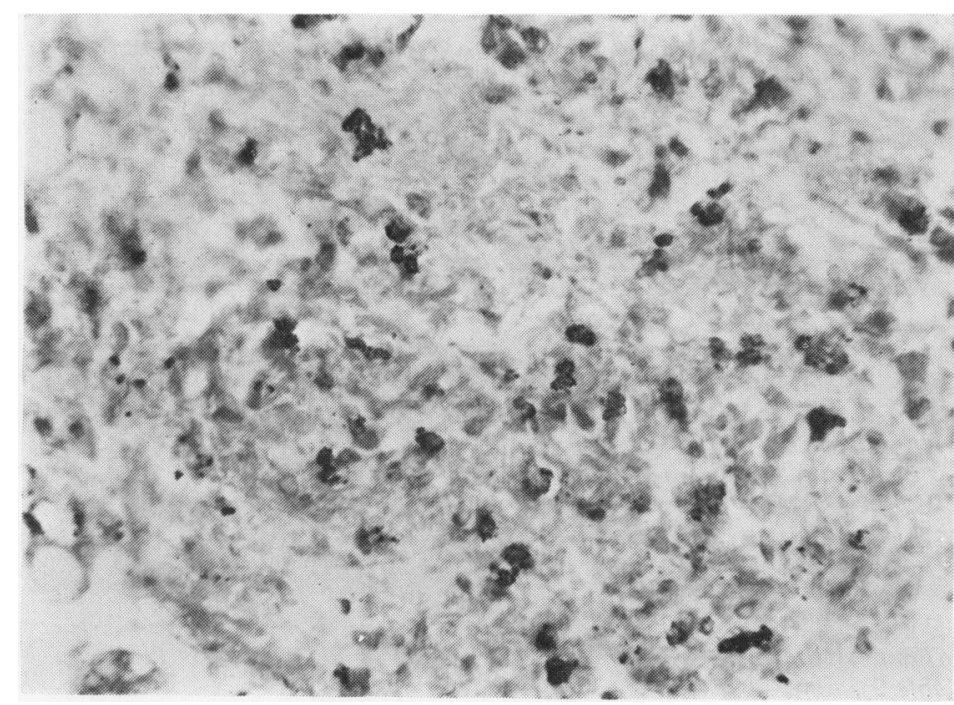

Fig. 6 Case 2. Liver. Aluminium inclusions (black in photograph) within a hepatic sarcoid granuloma (Aluminon method; $\times 265$ ). 
(a)

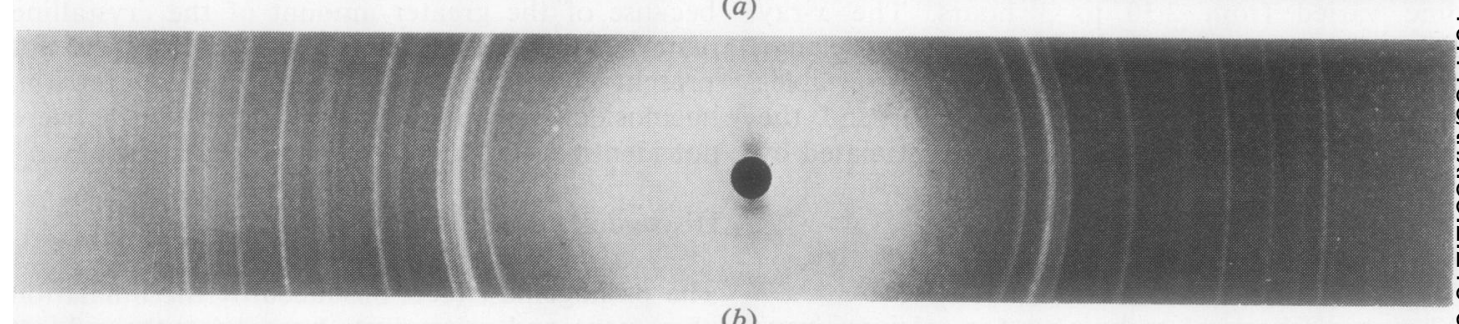

(b)

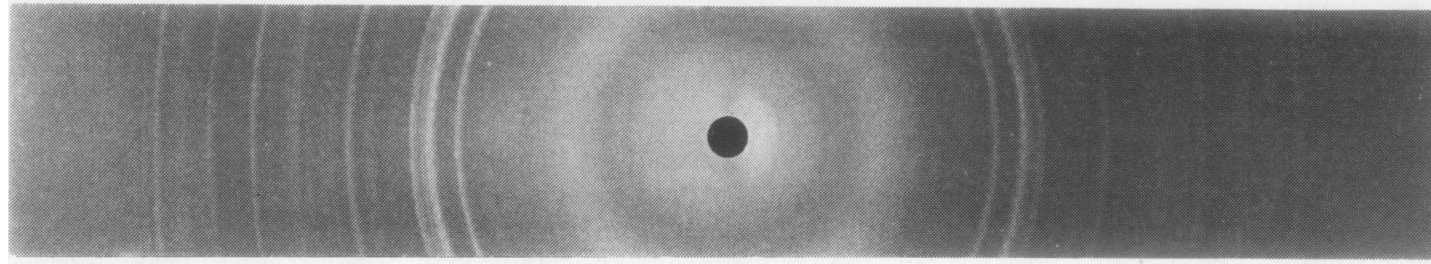

(c)

Fig. $7 \quad X$-ray diffraction pattern of Portland cement (a) and of the lung (b) and liver (c) of case 1. A strong pattern of the inhaled material can be recognised in the tissue radiograms (see Table 1).
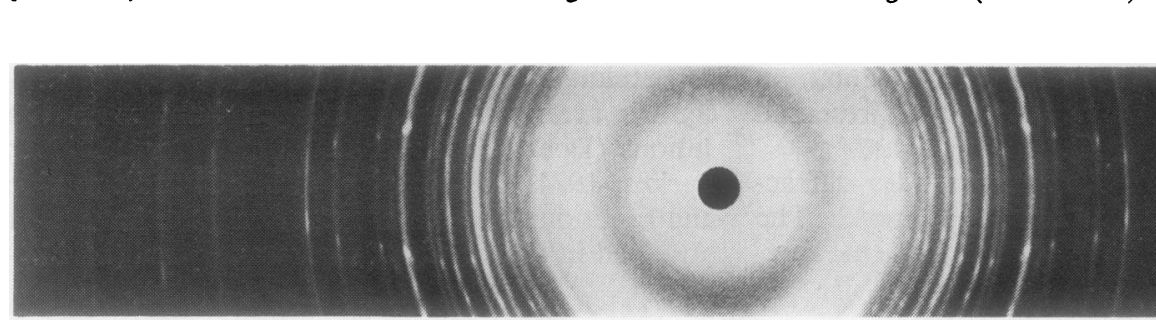

(a)
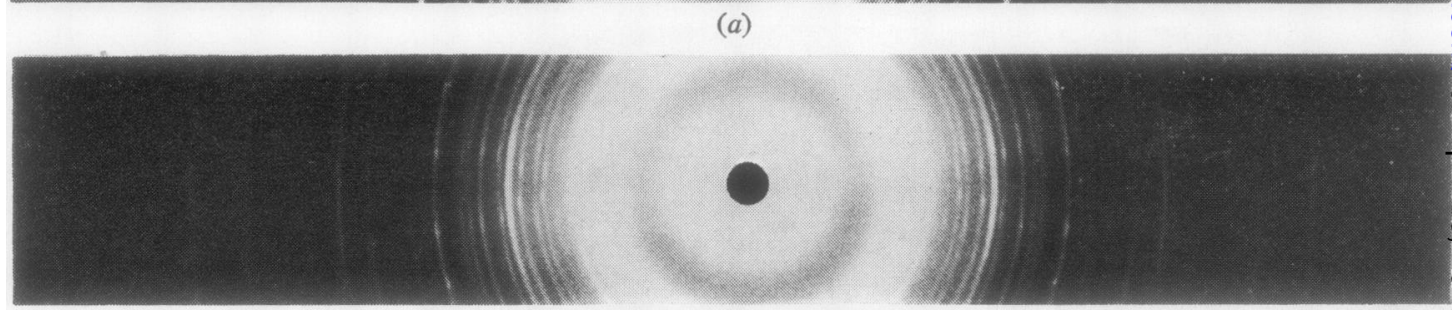

(b)
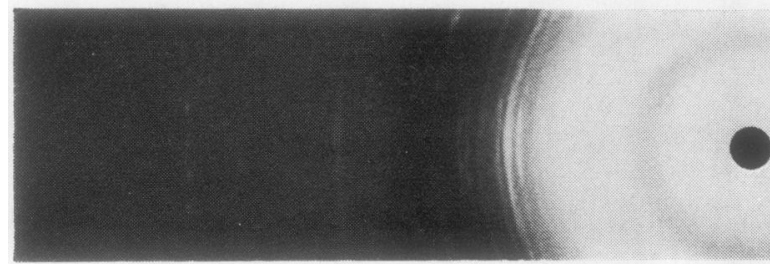

(c)

Fig. 8 X-ray diffraction of muscovite (a) and of the lung (b) and liver (c) of case 2. The muscovite pattern is evident in the tissue radiograms (see Table 2). 
Table 1 Case 1 . X-ray diffraction spacing data

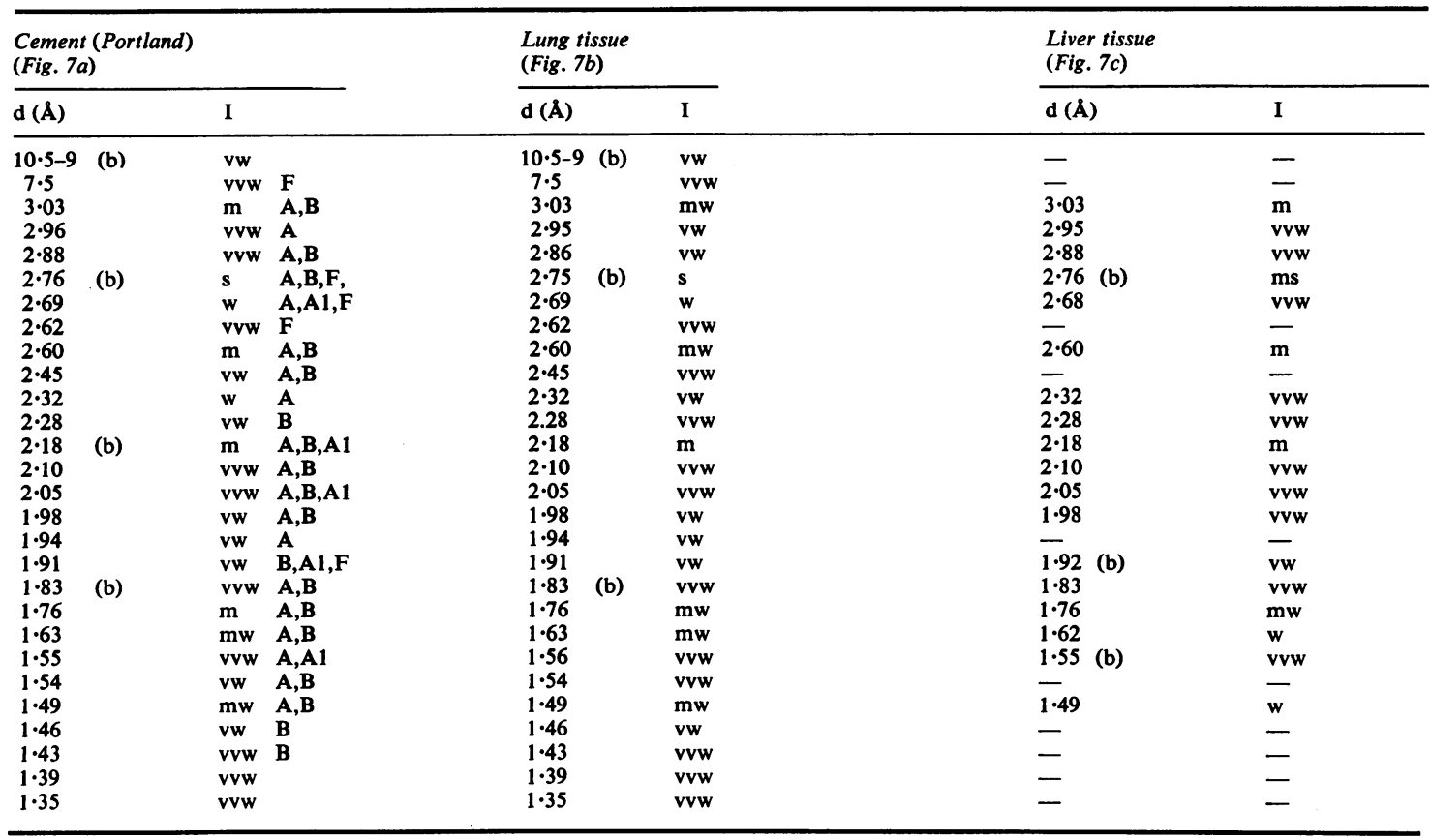

$\mathrm{d}=$ interplanar spacing; $\mathrm{b}=$ broad line; $\mathrm{I}=$ intensity; $\mathrm{s}=$ strong; $\mathrm{ms}=$ medium strong; $\mathrm{m}=$ medium; $\mathrm{mw}=$ medium weak; $w=w e a k ; \mathrm{v}=\mathrm{very}$ weak; vvw =very very weak; $\mathbf{A}=$ alite; $\mathbf{A} 1=$ tricalcium aluminate; $\mathbf{F}=$ ferrite; $\mathbf{M}=$ muscovite.

Table 2 Case 2. X-ray diffraction spacing data

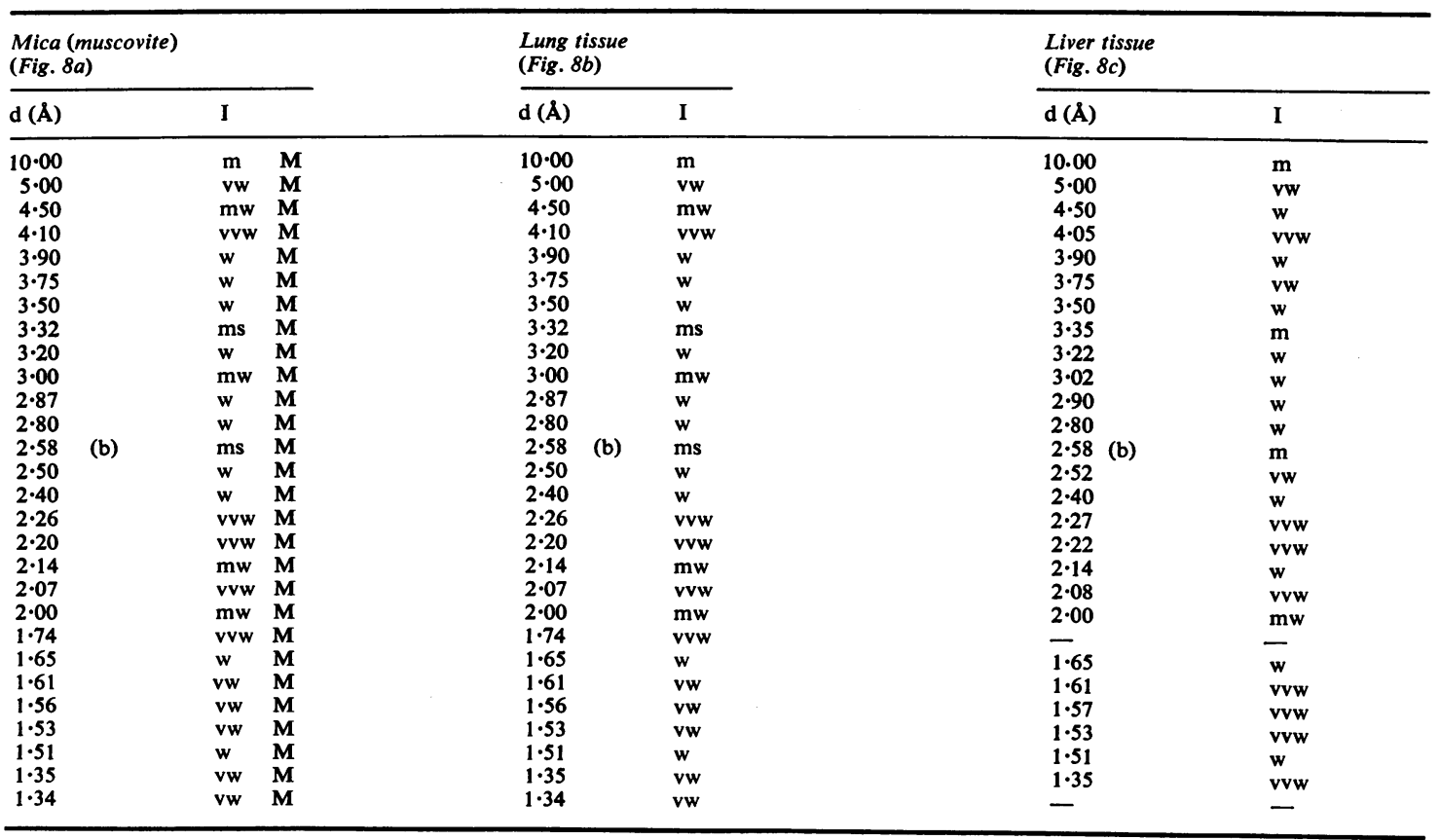

See footnote to Table 1. 
ton, 1936; Dreesen et al., 1940; Vestal et al., 1943; Tat and Simionescu, 1972), some authors have considered that mica dust is not harmful and could even have a protective action against other inhaled dusts (King et al., 1950). The only necropsy and pulmonary histopathological observations reported in a worker exposed to mica (biotite) are difficult to interpret, because in the case reported the patient had been exposed to other pathogenic dusts (Vorwald, 1960).

The present work describes the hepatic and pulmonary lesions observed in two patients exposed to cement and to mica dusts. The pulmonary lesions in the first case consisted of numerous histiocytic granulomas and irregular fibrohyaline scars with abundant inclusions of cement; these lesions were more frequent in the peribronchovascular connective tissue. The lung of the second case showed a diffuse thickening of all interalveolar septa by newly formed reticulin and collagen fibres and by proliferation of fibroblasts and histiocytes with inclusions of muscovite. There was no past history of other chest diseases nor record of exposure to other dusts in either case. Other exogenous contaminants were not identified by analysis of tissues at necropsy.

In addition to the pulmonary lesions, diffuse swelling and proliferation of the sinusoidal lining cells, sarcoid-type granulomas, and perisinusoidal and portal fibrosis were observed in the liver, closely related to inclusions of the inhaled dusts. It is likely that the inhaled cement and mica particles reach the liver by the bloodstream and produce these different types of hepatic lesion, as we proposed for Bordeaux mixture in a previous paper (Pimentel and Menezes, 1977).

In the last few years we have observed at necropsy and in surgical specimens the lung lesions of workers exposed to Portland cement dust with a low free silica content. The histopathological findings do not mimic those of silicosis, and the pulmonary lesions have been produced in guinea-pigs exposed to the same dust by inhalation (Pimentel and Gomes, 1973). It is conceivable, from our observations, that the aluminates and iron aluminates of calcium and the crystals of alite, belite, and tobermorite identified within the lesions are pathogenic to the lung and liver.

The aetiological diagnosis of hepatic granulomas, on morphological criteria, is often a puzzling problem, unless acid-fast bacilli, fungi, or ova of parasites are identified within the lesions. The inhalation of some kinds of dusts can also produce liver granulomas, as described in silicosis (Cisno et al., 1971), in berylliosis (Chesner, 1950), and in vineyard sprayer's lung (Pimentel and Menezes, $\stackrel{\vec{F}}{\vec{F}}$ 1975).

The present report adds two new aetiological varieties to sarcoid-like hepatic granuloma occurring in granulomatous disorders of inhalatory origin, and gives histopathological support to the results of some epidemiological surveys of workers exposed to cement and mica dusts (Middleton, 1936; Dreesen et al., 1940; Vestal et al., 1943; Hublet, 1968). The occupational exposure and the identification of the inhaled foreign material within the hepatic sarcoid-like granulomas are essential for the aetiological diagnosis and for the exclusion of other causes of hepatic granulomatosis and of i sarcoidosis (Pimentel and Menezes, 1977; Lancet, $\vec{\bullet}$ 1975).

We thank Eng. M. Olinda Braga for performing the $x$-ray diffraction analysis.

This work was supported by grants from the Instituto Nacional de Saude and Instituto de Alta Cultura of Portugal.

\section{References}

Baetjer, A. M. (1947). The effect of portland cement dust on the lungs with special references to suscepti- $\overparen{D}$ bility to lobar pneumonia. Journal of Industrial Hygiene and Toxicology, 29, 250-258.

Chesner, C. (1950). Chronic pulmonary granulomatosis in residents of a community near a beryllium plant: Three autopsied cases. Annals of Internal Medicine, 32, 1028-1048.

Cisno, F., Azzalini, M., and Camagna, M. T. (1971). Considerazione su 16 casi di silicosi del fegato e della milza. Medicina del Lavoro, 62, 378-385.

Doerr, W. (1952). Pneumokoniose durch Zementstaub. Эำ Virchows Archiv für Pathologische Anatomie und Physiologie und für Klinische Medizin, 322, 397- 익 427.

Dreesen, W. C., Dallavalle, J. M., Edwards, T. I., 옥 Sayers, R. R., Easom, H. F., and Trice, M. F. $>$ (1940). Pneumoconiosis among mica and pegmatite workers. U.S. Public Health Bulletin, No. 250, Washington, D.C.

Einbrodt, H. J., and Hentschel, D. (1966). Tierexperi- N mentelle Untersuchungen mit Arbeitsplatzstäuben N ans einem Hüttenzementwerk. Internationales $\omega$ Archiv für Gewerbepathologie und Gewerbehygiene, 22, 354-366.

Gardner, L. U., Durkan, T. M., Brumfiel, D. M., and Sampson, H. L. (1939). Survey in seventeen cement $\stackrel{\mathscr{C}}{+}$ plants of atmosphere dusts and their effects upon 0 the lungs of twenty-two hundred employees. Journal of Industrial Hygiene and Toxicology, 21, 279-318. จ

Giuliani, V., and Belli, R. (1955). Sul rischio profes- $\vec{D}$ sionale die cementisti (indagini clinico-statistiche). Medicina del Lavoro, 46, 715-724.

Hublet, P. (1968). Enquête relative au risque de pneu- 8 moconiose dans la fabrication des ciments de con- 
struction. Archives Belges de Médecine Sociale, Hygiène, Médecine du Travail et Médecine Légale, 26, 417-430.

Jenny, M., Bättig, K., Horisberger, B., Havas, L., and Grandjean, E. (1960). Arbeitsmedizinische Untersuchung in Zementfabriken. Schweizerische Medizinische Wochenschrift, 90, 705-709.

Jones, W. R. (1933). Silicotic lungs: The minerals they contain. Journal of Hygiene, 33, 307-329.

Kalačić, I. (1973). Chronic nonspecific lung disease in cement workers. Archives of Environmental Health, 26, 78-83.

King, E. J., Gilchrist, M., and Rae, M. V. (1947). Tissue reaction to sericite and shale dusts treated with hydrochloric acid: An experimental investigation on the lungs of rats. Journal of Pathology and Bacteriology, 59, 324-327.

King, E. J., Ray, S. C., Harrison, C. V., and Nagelschmidt, G. (1950). The effects of granite on the lungs of rats. British Journal of Industrial Medicine, 7, 37-41.

Lancet (1975). Editorial. Granulomas of the liver. Lancet, 2, 1079-1080.

Lemon, W. S., and Higgins, G. M. (1935). The tissue reactions of the lung to the intratracheal injection of particulate sericite, an experimental study. American Review of Tuberculosis, 32, 243-256.

Middleton, E. L. (1936). Industrial pulmonary disease due to the inhalation of dust. Lancet, 2, 59-64.

National Bureau of Standards (1950). Tables for conversion of X-ray diffraction angles to interplanar spacings. Applied Mathematics Series, Vol. 10, Government Printing Office, Washington, D.C.

Parkes, W. R. (1974). Occupational Lung Disorders, pp. 157-159, 346-347. Butterworth, London.

Pearse, A. G. E. (1972). Histochemistry Theoretical and Applied, 3rd edition, Vol. II. p. 1140. Churchill Livingstone, Edinburgh and London.
Pimentel, J. C., and Gomes, F. B. (1973). Pneumopatia por inalação da poeira do cimento. Bases anátomo-clínicas para a sua individualização e identificação. Jornal do Médico, 81, 11-19.

Pimentel, J. C., and Menezes, A. P. (1975). Liver granulomas containing copper in vineyard sprayer's lung. A new etiology of hepatic granulomatosis. American Review of Respiratory Disease, 111, 189195.

Pimentel, J. C., and Menezes, A. P. (1977). Liver disease in vineyard sprayers. Gastroenterology, 72, 275-283.

Sayers, R. R., Dallavalle, J. M., and Bloomfield, S. G. (1937). Occupational and environmental analysis of the cement, clay and pottery industries. U.S. Public Bulletin, No. 238, pp. 1-50.

Tat, M., and Simionescu, C. (1972). Modifications fonctionnelles respiratoires sous l'influence de concentrations variées de poussières. Archives des Maladies Professionnelles de Médecine du Travail et de Securité Sociale, 33, 553-558.

Tripsa, R., and Rotaru, G. (1966). Recherches expérimentales sur la pneumoconiose provoquée par la poussière de mica. Medicina del Lavoro, 57, 492500.

Vestal, T. F., Winstead, J. A., and Joliet, P. V. (1943). Pneumoconiosis among mica and pegmatite workers. Industrial Medicine and Surgery, 12, 11-14.

Vorwald, A. J. (1960). Diffuse fibrogenic pneumoconiosis. Industrial Medicine and Surgery, 29, 353358.

Requests for reprints to: Dr. Amadeu Peixoto de Menezes, Laboratory of Pathophysiology, National Cancer Institute, National Institutes of Health, Bldg 10, Rm 5B47, Bethesda, Md 20014, USA. 